\title{
PENGARUH NILAI PERMITIVITAS RELATIF TIDAK HOMOGEN TERHADAP PERFORMANSI PADA ANTENA MIKROSTRIP SINGLE LAYER PATCH SIRKULAR FREKUENSI $X-B A N D$
}

\author{
Wahyu Fadhilah ${ }^{1}$, Bambang Sumajudin ${ }^{2}$, Edwar $^{3}$ \\ 1, 2, 3Prodi S1 Teknik Telekomunikasi, Fakultas Teknik Elektro, Universitas Telkom, Bandung \\ Indonesia, 40257 \\ 1'wahyufadhilah@yahoo.co.id, ${ }^{2}$ sumajudin@telkomuniversity.ac.id, \\ 3 eduatgugel@gmail.com
}

\begin{abstract}
Abstrak
Antena mikrostrip merupakan antena yang sering digunakan untuk berbagai keperluan karena mempunyai beberapa kelebihan antara lain kecil, sederhana, dan murah. Dibalik kelebihan itu, terdapat beberapa kekurangan yaitu mempunyai Bandwidth yang kecil dan Gain yang kecil. Substrat tidak homogen telah digunakan untuk menurunkan indeks dielektrik yang efektif dari substrat Homogen, menekan gelombang permukaan yang berasal dari sebuah patch, dan meningkatkan pola radiasi dari patch. Pada penelitian ini, didapatkan hasil performansi yang lebih baik pada antena dengan menggunakan substrat tidak homogen. Performansi antena yang paling baik berupa peningkatan bandwidth sebesar 128,15 MHz (29,558\%), gain sebesar $0.8076 \mathrm{dBi}(11,855 \%)$, dan frekuensi tengah dari antena bergeser ke kanan (bertambah) sebesar 1,0075 GHz $(9,842 \%)$ daripada performansi dengan substrat homogen.
\end{abstract}

Kata Kunci: Kata kunci sedapat mungkin menjelaskan isi tulisan, dan ditulis dengan huruf kecil, kecuali akronim. Kata kunci tidak lebih dari 6 kata.

\section{Abstract}

The abstract should state briefly the general aspects of the subject and the main conclusions. The length of abstract should be no more than 200 words.

Key Words: keyword should be chosen that they best describe the contents of the paper and should be typed in lower-case, except proper nouns and acronyms. Keyword should be no more than 6 words.

\section{Pendahuluan}

Antena mikrostrip merupakan antena yang sering digunakan untuk berbagai keperluan karena mempunyai beberapa kelebihan antara lain kecil, sederhana, dan murah. Dibalik kelebihan itu, terdapat beberapa kekurangan yaitu mempunyai Bandwidth yang kecil dan Gain yang kecil. Pada dasarnya, menggunakan substrat dengan nilai permitivitas yang rendah akan menghasilkan bandwidth yang besar tetapi dengan dimensi yang lebih besar dan gain yang kecil. Sebaliknya, menggunakan substrat dengan nilai permitivitas yang tinggi akan menghasilkan gain yang besar dan dimensi yang lebih kecil tetapi dengan bandwidth yang kecil [1].

Antena memiliki 3 bagian, yaitu Ground Plane, Substrat, dan Patch. Setiap bagian mempunyai bahan yang berbeda. Pada penelitian sebelumnya, ground plane dan patch memiliki bahan yang sama yaitu copper, sedangkan substrat bisa memiliki bahan yang berbeda. Dalam hal ini, bahan substrat yang digunakan adalah Roger RT5880 dengan permitivitas relatif 2,2 dengan ketebalan 1,588 mm. Teknik pencatuan yang digunakan yaitu Microstrip Line Feed [2].

Peningkatan performansi antena sangat diperlukan. Jenis antena mikrostrip merupakan jenis antena yang dapat di kembangkan lebih lanjut lagi. Terdapat banyak metode yang dapat dilakukan untuk meningkatkan performansi antena. Dalam hal ini penulis akan mengangkat topik tentang Pengaruh Nilai Permitivitas Relatif tidak Homogen Terhadap Performansi pada Antena Mikrostrip Single Layer Patch Sirkular Frekuensi $X$-Band. Diharapkan dengan merubah nilai dielektrik yang selama ini bernilai konstan pada sebuah antena mikrostrip dapat 
meningkatkan performansi antena sehingga dapat memperkecil kelemahan dari antena mikrostrip.

Pada Studi lainnya digunakan substrat tidak homogen untuk meningkatkan bandwidth dan gain pada antena. Dengan menggunakan substrat dengan nilai permitivitas relatif tidak sama pada suatu antena mikrostrip yaitu udara, Rogers RU-3003, dan Rogers RT/Duroid-5880. Substrat tidak homogen ini telah digunakan untuk menurunkan indeks dielektrik yang efektif dari substrat Homogen, menekan gelombang permukaan yang berasal dari sebuah patch, mengurangi hilangnya penyisipan filter, meningkatkan pola radiasi dari patch dan mengurangi mutual coupling di antara antena elemen array [3][4][5].

\section{KONSEP DASAR}

\subsection{Antena Mikrostrip}

Antena Mikrostrip adalah salah satu jenis antena yang sangat populer. Antena mikrostrip memiliki sifat yang konformal sehingga dapat ditempatkan pada semua jenis permukaan. Dengan sifat yang dimiliki oleh antena mikrostrip, antena mikrostrip sangat sesuai dengan kebutuhn industri telekomunikasi saat ini sehingga dapat digunakan oleh perangkat telekomunikasi bahkan dengan ukuran paling kecil sekalipun. Antena mikrostrip terbagi menjadi 3 bagian yaitu, Patch, substrate, dan ground plane [6].

\subsection{Substrat}

Substrat pada antena mikrostrip terbuat dari bahan dielektrik yang mempunyai fungsi sebagai media penyalur gelombang elektromagnetik dari catuan. Bahan substrat pada antena mikrostrip dapat berdasarkan karakteristik material yang diinginkan untuk daya yang optimal pada suatu jarak frekuensi tertentu. Spesifikasi umum substrat pada antena mikrostrip termasuk nilai konstanta permitivitas relatif, faktor disipasi (loss tangent), dan ketebalan. Tabel 1 menunjukkan Substrat pada antena mikrostrip mempunyai nilai konstanta permitivitas relatif antara $2,2<\varepsilon r<12$ digunakan pada frekuensi dari 1 hingga $100 \mathrm{GHz}$ [6].

Substrat heterogen menghasilkan nilai yang berbeda permitivitas pada lokasi yang berbeda dalam substrat dan digunakan untuk meningkatkan kinerja elektromagnetik antena mikrostrip. Substrat ini telah digunakan untuk menurunkan indeks dielektrik yang efektif dari substrat Homogen, menekan gelombang permukaan yang berasal dari sebuah Patch, mengurangi hilangnya penyisipan filter, meningkatkan pola radiasi dari Patch dan mengurangi mutual coupling di antara antena elemen array [3].
Tabel 1. Nilai Permitivitas Relatif berdasarkan jenis bahan

\begin{tabular}{|c|c|}
\hline Jenis Bahan & Permitivitas Relatif $(\varepsilon r)$ \\
\hline Udara & 1 \\
\hline Foam & 1.07 \\
\hline Fr-4 Epoxy & 4.4 \\
\hline RT/Duroid 5880 & 2.2 \\
\hline Polysterene-quartz & 2.6 \\
\hline Teflon-ceramic & 2.3 \\
\hline Polyolefin-ceramic & 310 \\
\hline Polyster-ceramic & 6 \\
\hline
\end{tabular}

\section{PERANCANGAN}

\subsection{Spesifikasi Antena}

Sebelum melakukan perancangan, terlebih dahulu menentukan spesifikasi antena yang diinginkan. Yaitu antena mikrostrip dengan bentuk Patch sirkular. Berikut adalah spesifikasi yang diinginkan seperti pada Tabel 2.

Tabel 2. Spesifikasi Antena

\begin{tabular}{|c|c|}
\hline Frekuensi Kerja & $10 \mathrm{GHz}$ \\
\hline Range Nilai $\varepsilon r$ & $+25 \%$ \\
\hline VSWR & $i^{2}$ \\
\hline Return Loss & $i-10$ \\
\hline Bentuk Patch & Sirkular \\
\hline Teknik Pencatuan & Microstrip Line Feed \\
\hline
\end{tabular}

\subsection{Pemilihan Bahan Antena}

Parameter yang dipertimbangkan dalam penelitian kali ini adalah ketebalan substrat (h) dan konstanta permitivitas relatif $(\varepsilon r)$. Bahan substrat yang digunakan adalah Roger RT5880 yang memiliki nilai permitivitas relatif $(\varepsilon r)=2,2$ dengan ketebalan substrat (h)=1,588 mm. Untuk pemilihan bahan substrat untuk meningkatkan performansi antena dapat menyesuaikan dengan kebutuhan atau sampai terdapat peningkatan performansi yang diinginkan.

\subsection{Skenario Penelitian}

Setelah perancangan antena mikrostrip Patch sirkular, dilakukan peningkatan performansi antena dengan merubah nilai permitivitas relatif menjadi tidak homogen dengan konfigurasi pada Gambar 1. Range modifikasi nilai permitivitas relatif yang digunakan antara $1,652,75(+25 \%$ dari nilai permitivitas relatif yang digunakan). Untuk melihat apakah performansi sudah lebih baik dilihat dari parameter antena tersebut yaitu VSWR, Gain, dan Efisiensi. 


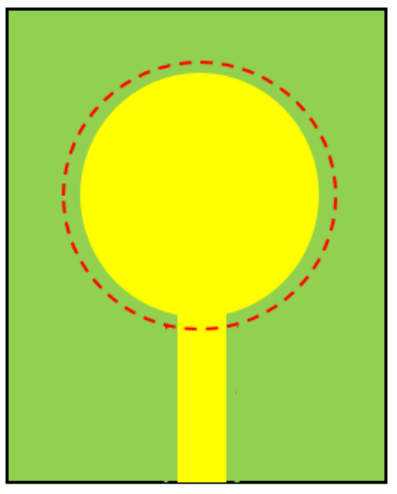

\section{Gambar 1. Rancangan konfigurasi nilai permitivitas relatif tidak homogen}

\subsection{Desain Antena}

Desain antena yang dirancang memiliki 3 bagian yaitu Ground Plane, substrat, dan patch. Patch antena mikrostrip yang digunakan berbentuk sirkular. Bentuk antena tampak depan dapat diilustrasikan pada Gambar 2. Sedangkan bentuk antena tampak samping diilustrasikan pada Gambar 3.

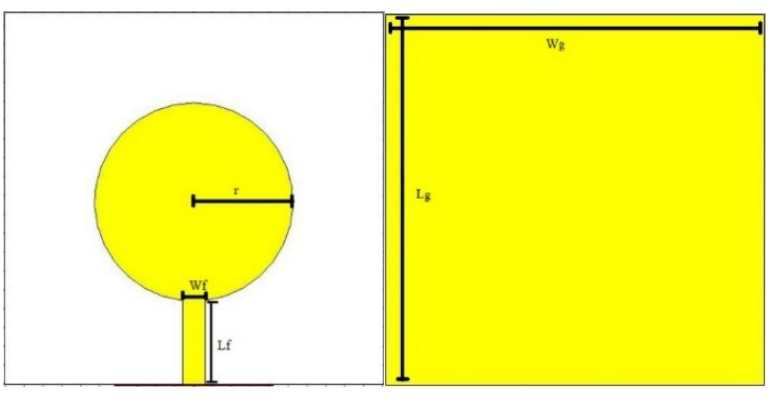

(a)

(b)

Gambar 2. Antena tampak (a) depan (b)belakang

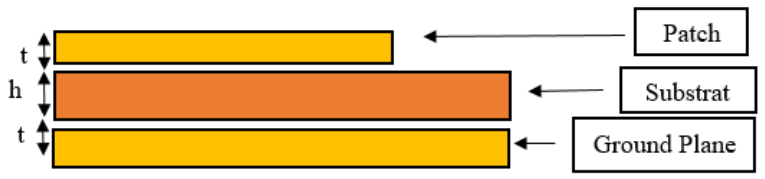

Gambar 3. Antena tampak samping.

Untuk menentukan dimensi dari patch sirkular, dapat digunakan persamaan berikut [6]:

$$
\begin{aligned}
F & =\frac{8,971 \times 10^{9}}{f_{r \sqrt{\varepsilon_{r}}}} \\
a & =\frac{F}{\left\{1+\frac{2 h}{\pi \varepsilon_{r} F\left[\ln \left(\frac{\pi F}{2 h}\right)+1,7726\right]}\right\}^{\frac{1}{2}}} \\
r & =a\left\{1+\frac{2 h}{\pi a \varepsilon_{r}}\left[\ln \left(\frac{\pi a}{2 h}\right)+1,7726\right]\right\}^{\frac{1}{2}}
\end{aligned}
$$

Dimana $f r$ adalah Frekuensi resonansi atau frekuensi kerja $(\mathrm{Hz}), \varepsilon_{r}$ adalah Konstanta permitivitas relatif substrat, $h$ adalah Tebal substrat (mm), dan $a$ adalah Jari-jari patch $(\mathrm{mm})$. Pada umumnya, dimensi dari ground plane dapat ditentukan melalui persamaan berikut:

$$
\begin{aligned}
W_{g} & =2 a+6 h \\
L_{g} & =L_{f}+2 a+3 h
\end{aligned}
$$

Dimana $W_{g}$ adalah lebar dari ground plane $(\mathrm{mm})$ dan $L_{g}$ adalah panjang dari ground plane $(\mathrm{mm})$.

Tabel 3 menunjukkan parameter antena yang digunakan untuk antena homogen dan tidak homogen yang terlebih dahulu dilakukan simulasi apakah parameter antena tersebut sudah mendapatkan hasil parameter yang optimal.

Tabel 3. Parameter Dimensi Antena

\begin{tabular}{|c|c|c|}
\hline Nama & Nilai (mm) & Deskripsi \\
\hline r & 5.25 & Jari-jari Patch \\
\hline wf & 1.2 & Lebar Feedline \\
\hline ff & 4.4 & Panjang Feedline \\
\hline t & 0.05 & Tebal Feedline \\
\hline h & 1.588 & Tebal Substrat \\
\hline wg & 20.028 & Lebar Ground Plane \\
\hline lg & 19.664 & Panjang Ground Plane \\
\hline
\end{tabular}

\subsection{Skenario Penelitian antena dengan substrat tidak homogen}

Pada penelitian ini dilakukan simulasi antena dengan substrat homogen terlebih dahulu. Setelah parameter antena dengan substrat homogen sudah optimal, dirancang antena dengan substrat tidak homogen menggunakan dimensi antena homogen yang sudah optimal. Perancangan antena tidak homogen di bagi menjadi 3 skenario yaitu 5 segmen, 9 segmen, dan 13 segmen seperti ditunjukkan pada Gambar 4, 5, dan 6. Dengan ukuran normal setiap segmen adalah 0,25 $\mathrm{mm}$. hasil parameter selanjutnya akan diverifikasi dengan 2 simulator. Parameter yang dibandingkan adalah Bandwidth dan Gain.

Range nilai yang akan digunakan pada antena tidak homogen yaitu $18 \%$ dan $25 \%$. Setiap range nilai pada setiap segmen dilakukan meningkat dan juga menurun. Untuk range nilai $25 \%$ memiliki range nilai meningkat 2,2-2,75, sedangkan untuk yang menurun 2,2-1,65. Untuk range nilai $18 \%$ memiliki range nilai meningkat 2,2-2,59, sedangkan yang menurun 2,2-1,81. 


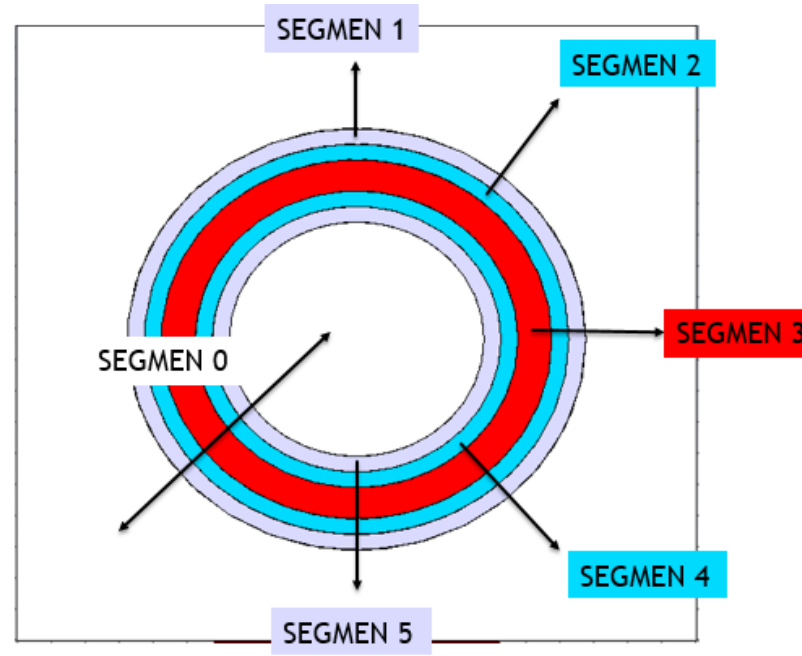

(a)

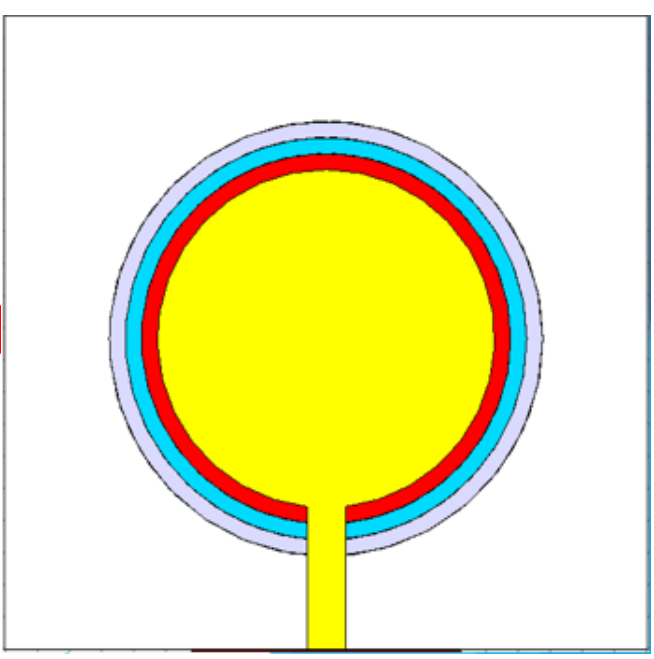

(b)

Gambar 4. Antena Substrat Tidak Homogen 5 segmen (a) Patch disembunyikan, (b) Patch diperlihatkan

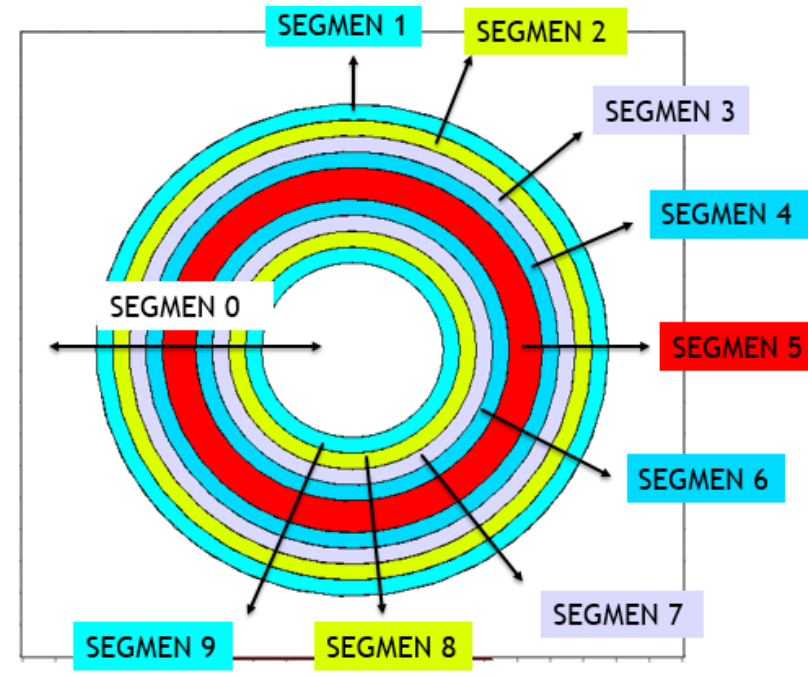

(a)

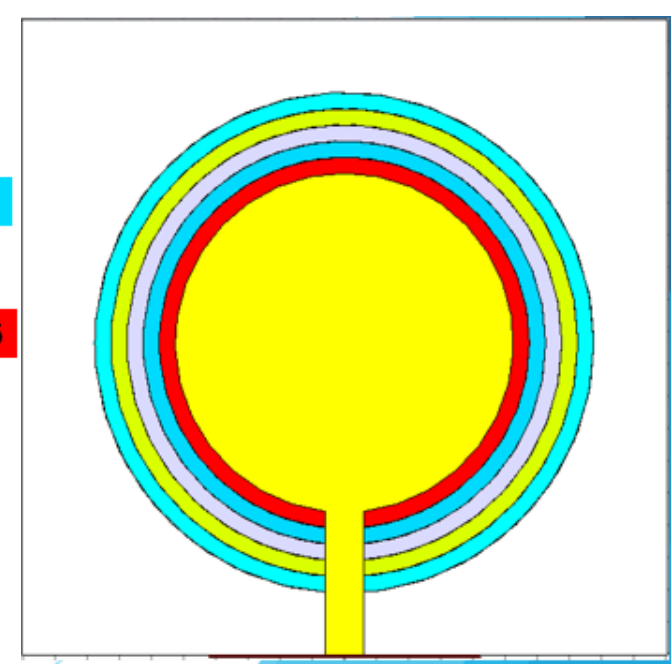

(b)

Gambar 5. Antena Substrat Tidak Homogen 9 segmen (a) Patch disembunyikan, (b) Patch diperlihatkan

\section{ANALISIS}

\subsection{Parameter Antena dengan Substrat Homogen $\varepsilon_{r}=\mathbf{2 , 2}$}

Digunakan 2 simulator untuk memverifikasi hasil simulasi. Selanjutnya hasil simulasi akan dianalisis apakah perancangan antena substrat Tidak Homogen dapat menghasilkan performansi yang lebih baik dari antena substrat homogen. Parameter yang diamati yaitu Bandwidth dan Gain.

Pada simulasi antena dengan substrat homogen didapatkan Bandwidth $433 \mathrm{MHz}$ pada simulator 1 dan sebesar 434,1 MHz pada simulator 2. Dapat diamati nilai Bandwidth pada simulator 2 lebih besar dibandingkan dengan nilai pada simulator 1 . Didapatkan hasil simulasi nilai Gain pada 2 simulator. Nilai Gain untuk antena dengan substrat homogen pada simulator 1 yaitu $6,313 \mathrm{~dB}$, sedangkan nilai Gain pada simulator 2 yaitu 7,7797 $\mathrm{dB}$. Untuk jenis pola radiasi untuk antena dengan substrat homogen pada 2 simulator yaitu Unidirectional dengan side back lobe yang kecil.

\subsection{Parameter Antena dengan Substrat Homogen $\varepsilon_{r}=\mathbf{1 , 6 5}$}

Antena dengan substrat homogen pada dimensi yang sama, jika nilai permitivitas relatif diturunkan menjadi 1,65 (25\%) maka dihasilkan nilai bandwidth dan gain yang lebih besar dengan frekuensi tengah yang bergeser ke kanan. Peningkatan nilai bandwidth yang terjadi sebesar $137,1 \mathrm{MHz}$ atau sebesar $31,62 \%$ daripada nilai bandwidth dengan substrat homogen $\varepsilon_{r}=2,2$. Sedangkan peningkatan nilai gain yang terjadi sebesar $1,0456 \mathrm{dBi}$ atau sebesar $15,35 \%$ 


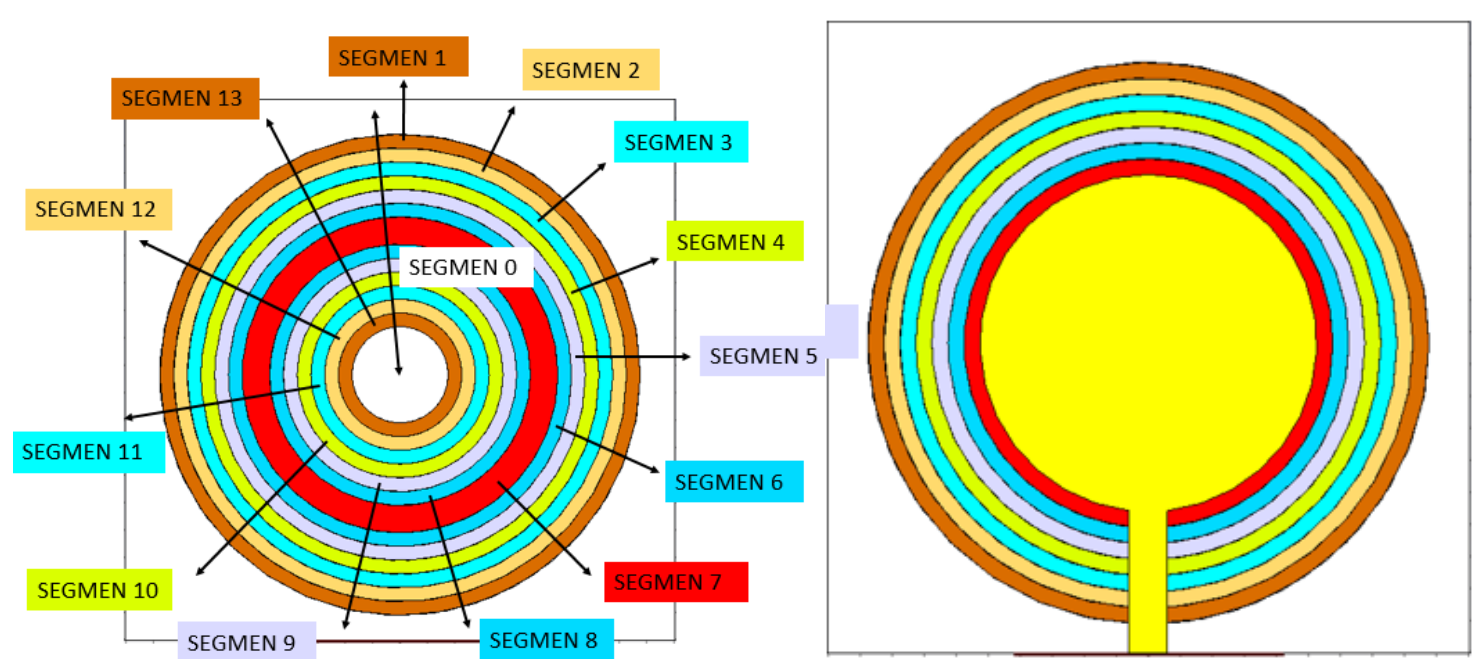

(a)

(b)

Gambar 6. Antena Substrat Tidak Homogen 13 segmen (a) Patch disembunyikan, (b) Patch diperlihatkan

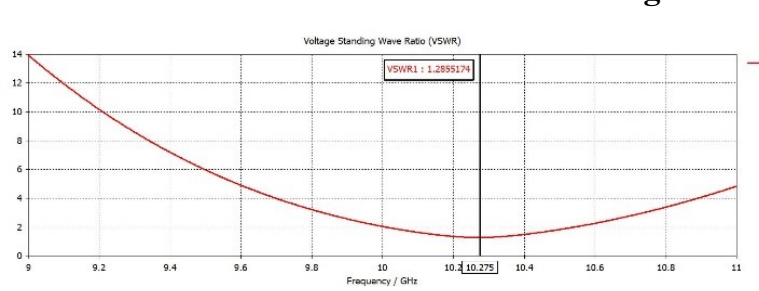

(a)

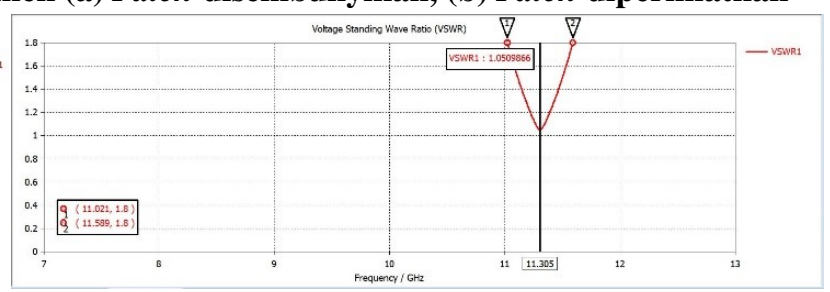

(b)

Gambar 7. Antena Substrat Tidak Homogen 13 segmen (a) Patch disembunyikan, (b) Patch diperlihatkan

daripada nilai gain dengan substrat homogen $\varepsilon_{r}=2,2$.

\subsection{Parameter Antena dengan Substrat Homogen $\varepsilon_{r}=\mathbf{2 , 7 5}$}

Antena dengan substrat homogen pada dimensi yang sama, jika nilai permitivitas relatif dinaikkan menjadi 2,75 (25\%) maka dihasilkan nilai bandwidth dan gain yang lebih kecil dengan frekuensi tengah yang bergeser ke kiri. Penurunan nilai bandwidth yang terjadi sebesar 228,35 $\mathrm{MHz}$ atau sebesar 52,67\% daripada nilai bandwidth dengan substrat homogen $\varepsilon_{r}=2,2$. Sedangkan penurunan nilai gain yang terjadi sebesar $0,49525 \mathrm{dBi}$ atau sebesar 7,27\% daripada nilai gain dengan substrat homogen $\varepsilon_{r}=2,2$.

\subsection{Parameter Antena dengan Substrat Tidak Homogen}

Dari hasil simulasi didapatkan adanya perubahan nilai Bandwidth. Untuk peningkatan range nilai ketika diperbesar sebanyak 2 sampai 3 kali dari ukuran normal segmen, nilai Bandwidth akan mengalami penurunan dan ketika diperkecil akan mengalami peningkatan. Untuk penurunan range nilai ketika diperbesar sebanyak 2 sampai 3 kali dari ukuran normal segmen nilai Bandwidth mengalami peningkatan dan ketika diperkecil akan mengalami penurunan. Untuk frekuensi tengah dari antena akan bergeser ke kanan (bertambah) pada saat ukuran segmen diperkecil dan akan bergeser ke kiri (berkurang) pada saat ukuran segmen diperbesar baik pada simulator 1 maupun simulator 2. Pada penelitian ini didapatkan hasil Gain dan pola radiasi antena. Untuk peningkatan range nilai ketika diperbesar sebanyak 2 sampai 3 kali dari ukuran normal segmen nilai Gain akan mengalami penurunan nilai, sedangkan ketika diperkecil akan mengalami peningkatan. Untuk penurunan range nilai ketika diperbesar sebanyak 2 sampai 3 kali dari ukuran normal segmen nilai Gain akan mengalami peningkatan nilai, sedangkan ketika diperkecil akan mengalami penurunan. Pada simulator 2 untuk range nilai turun ketika diperbesar maupun diperkecil nilai Gain akan mengalami peningkatan.

\subsection{Analisis Perubahan Performansi Antena}

Analisis perubahan performansi antena yang dilakukan pada penelitian ini adalah membandingkan antena substrat homogen dengan skenario penelitian antena tidak homogen yang telah dilakukan.

Dari simulasi yang sudah dilakukan, terdapat pola yang berulang dari modifikasi substrat tidak homogen. Pada kondisi peningkatan nilai permitivitas relatif, semakin besar jumlah segmen dan range nilai 


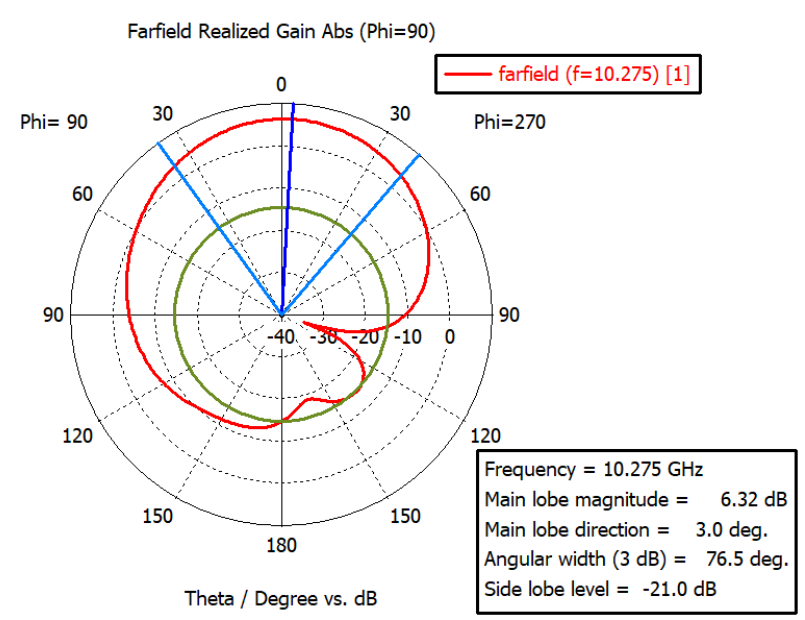

(a)

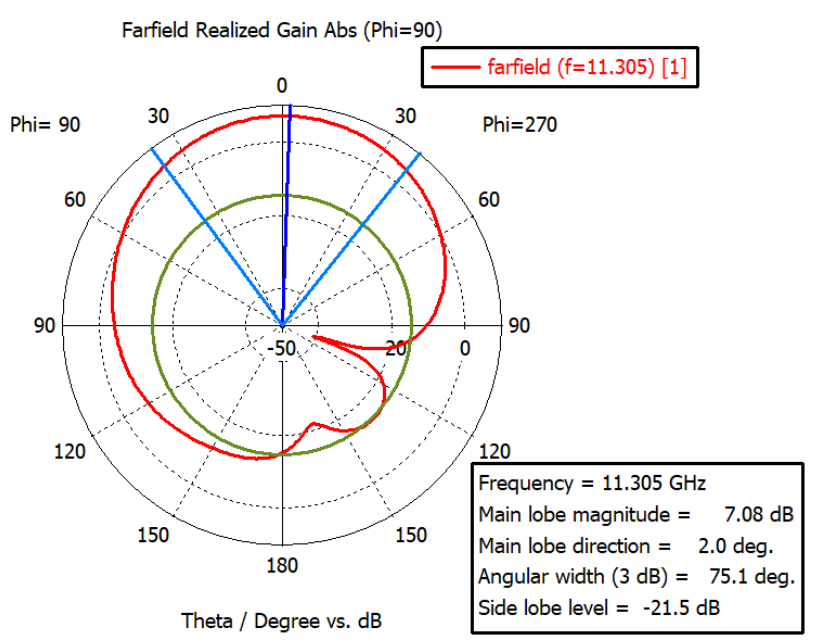

(c)

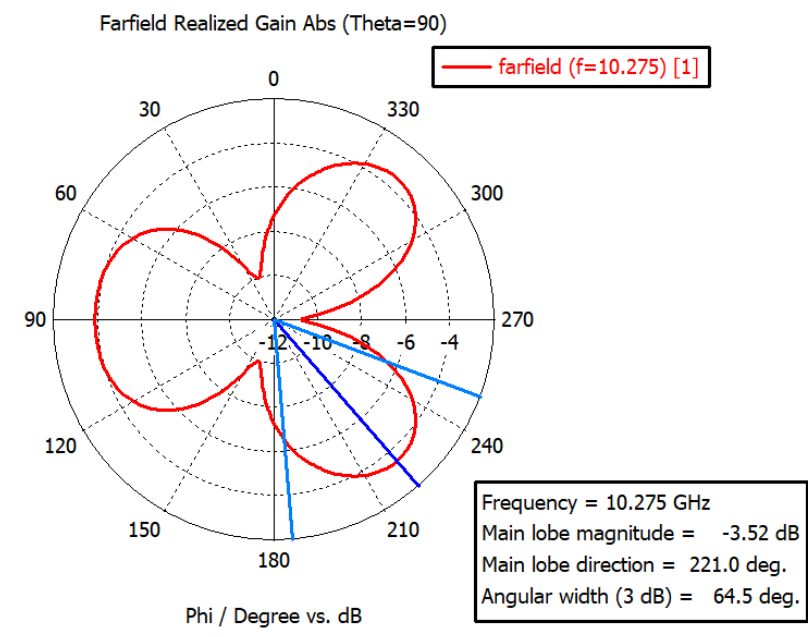

(b)

Farfield Realized Gain Abs (Theta $=90$ )

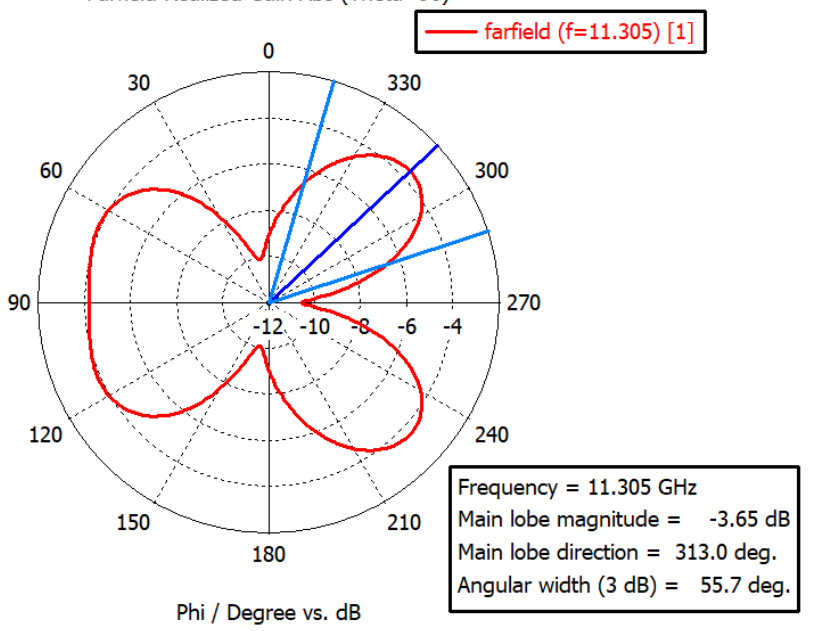

(d)

Gambar 8. Hasil gain antena, (a) substrat dengan nilai permitivitas relatif homogen bidang azimuth, (b) substrat dengan nilai permitivitas relatif homogen bidang elevasi, (c) substrat 13 segmen dengan penurunan nilai permitivitas relatif tidak homogen $25 \%$ untuk lebar $0,5 \mathrm{~mm}$ bidang azimuth, dan (d) substrat 13 segmen dengan penurunan nilai permitivitas relatif tidak homogen $25 \%$ untuk lebar $0,5 \mathrm{~mm}$ bidang elevasi.

permitivitas maka nilai bandwidth akan semakin kecil, frekuensi tengah akan bergeser ke kiri (berkurang), dan gain akan semakin kecil. Pada kondisi penurunan nilai permitivitas relatif, semakin besar jumlah segmen dan range nilai permitivitas maka nilai bandwidth akan semakin besar, frekuensi tengah akan bergeser ke kanan (bertambah), dan gain akan semakin besar.

Antena dengan substrat homogen pada dimensi yang sama, jika nilai permitivitas relatif diturunkan menjadi 1,65 (25\%) maka dihasilkan nilai bandwidth dan gain yang lebih besar dengan frekuensi tengah yang bergeser ke kanan. Untuk frekuensi tengah yang sama dengan substrat tidak homogen 13 segmen dengan range nilai permitivitas relatif sebesar $25 \%$ dan lebar segmen sebesar $0,5 \mathrm{~mm}$, didapatkan nilai gain yang lebih besar, nilai bandwidth yang lebih kecil, dan ukuran patch yang lebih besar. Sebaliknya, jika nilai permitivitas relatif dinaikkan menjadi 2,75 (25\%) maka dihasilkan nilai bandwidth dan gain yang lebih kecil dengan frekuensi tengah yang bergeser ke kiri.

Untuk mendapatkan nilai bandwidth yang optimal digunakan substrat tidak homogen 13 segmen dengan nilai permitivitas relatif diturunkan sebesar $25 \%$ untuk lebar segmen $0,5 \mathrm{~mm}$. Peningkatan nilai bandwidth yang terjadi sebesar $128,15 \mathrm{MHz}$ $(29,558 \%)$ daripada nilai bandwidth dengan substrat homogen seperti yang ditunjukkan pada Gambar 7 . Peningkatan nilai gain yang terjadi sebesar $0.8076 \mathrm{dBi}$ $(11,855 \%)$ seperti yang ditunjukkan pada Gambar 8 dan frekuensi tengah dari antena bergeser ke kanan 
Tabel 4. Nilai performansi antena hasil simulasi berdasarkan 2 simulator

\begin{tabular}{|c|c|c|c|c|c|c|c|c|c|c|c|}
\hline No & $\begin{array}{c}\text { Nilai } \\
\text { Permitivitas } \\
\text { Relatif }\end{array}$ & $\begin{array}{l}\text { Ukuran } \\
\text { Segmen } \\
(\mathrm{mm})\end{array}$ & $\begin{array}{c}\text { Frekuensi } \\
\text { Tengah } \\
(\mathrm{GHz})\end{array}$ & $\begin{array}{c}\text { BW di } \\
\text { VSWR } \\
<1,5 \\
(\mathrm{MHz})\end{array}$ & $\begin{array}{l}\text { Gain } \\
(\mathrm{dBi})\end{array}$ & No & $\begin{array}{c}\text { Nilai } \\
\text { Permitivitas } \\
\text { Relatif }\end{array}$ & $\begin{array}{l}\text { Ukuran } \\
\text { Segmen } \\
(\mathrm{mm})\end{array}$ & $\begin{array}{c}\text { Frekuensi } \\
\text { Tengah } \\
(\mathrm{GHz})\end{array}$ & $\begin{array}{c}\text { BW di } \\
\text { VSWR } \\
<1,5 \\
(\mathrm{MHz})\end{array}$ & $\begin{array}{l}\text { Gain } \\
(\mathrm{dBi})\end{array}$ \\
\hline 1 & \multicolumn{2}{|c|}{$\begin{array}{l}\text { Homogen } \\
2,75 \text { (FS) }\end{array}$} & 9,528 & 207,7 & 6,39 & 22 & \multicolumn{2}{|c|}{ Homogen 1,65 (DS) } & 11,587 & 570,6 & 7,86 \\
\hline 2 & \multicolumn{2}{|c|}{$\begin{array}{l}\text { Homogen } \\
2,75 \text { (DS) }\end{array}$} & 9,279 & 205,2 & 6,32 & 23 & \multicolumn{2}{|c|}{ Homogen 1,65 (FS) } & 11,245 & 539,5 & 7,82 \\
\hline 3 & \multirow{3}{*}{$\begin{array}{l}\text { Meningkat } \\
25 \% \\
13 \text { Segmen }\end{array}$} & 0,25 & 9,682 & 326,9 & 6,70 & 24 & \multirow{3}{*}{$\begin{array}{c}\text { Menurun } \\
18 \% \\
5 \text { Segmen }\end{array}$} & 0,25 & 10,536 & 475,8 & 7,14 \\
\hline 4 & & 0,5 & 9,459 & 257,2 & 6,54 & 25 & & 0,5 & 10,722 & 503,5 & 7,28 \\
\hline 5 & & 0,125 & 9,887 & 373,0 & 6,79 & 26 & & 0,125 & 10,429 & 456,8 & 7,00 \\
\hline 6 & \multirow{3}{*}{$\begin{array}{c}\text { Meningkat } \\
18 \% \\
13 \text { Segmen }\end{array}$} & 0,25 & 9,841 & 365,0 & 6,80 & 27 & \multirow{3}{*}{$\begin{array}{l}\text { Menurun } \\
25 \% \\
5 \text { Segmen }\end{array}$} & 0,25 & 10,662 & 491,2 & 7,22 \\
\hline 7 & & 0,5 & 9,677 & 323,3 & 6,69 & 28 & & 0,5 & 10,931 & 527,5 & 7,42 \\
\hline 8 & & 0,125 & 9,988 & 390,4 & 6,85 & 29 & & 0,125 & 10,503 & 470,3 & 7,07 \\
\hline 9 & \multirow{3}{*}{$\begin{array}{l}\text { Meningkat } \\
25 \% \\
9 \text { Segmen }\end{array}$} & 0,25 & 9,760 & 349,7 & 6,78 & 30 & \multirow{3}{*}{$\begin{array}{l}\text { Menurun } \\
18 \% \\
9 \text { Segmen }\end{array}$} & 0,25 & 10,640 & 493,5 & 7,17 \\
\hline 10 & & 0,5 & 9,536 & 288,6 & 6,59 & 31 & & 0,5 & 10,852 & 523,4 & 7,33 \\
\hline 11 & & 0,125 & 9,948 & 384,0 & 6,03 & 32 & & 0,125 & 10,493 & 471,5 & 7,02 \\
\hline 12 & \multirow{3}{*}{$\begin{array}{l}\text { Meningkat } \\
18 \% \\
9 \text { Segmen }\end{array}$} & 0,25 & 9,898 & 379,0 & 6,81 & 33 & \multirow{3}{*}{$\begin{array}{l}\text { Menurun } \\
25 \% \\
9 \text { Segmen }\end{array}$} & 0,25 & 10,806 & 516,0 & 7,22 \\
\hline 13 & & 0,5 & 9,737 & 343,1 & 6,70 & 34 & & 0,5 & 11,116 & 554,2 & 7,50 \\
\hline 14 & & 0,125 & 10,036 & 400,4 & 6,90 & 35 & & 0,125 & 10,592 & 482,5 & 7,07 \\
\hline 15 & \multirow{3}{*}{$\begin{array}{l}\text { Meningkat } \\
25 \% \\
5 \text { Segmen }\end{array}$} & 0,25 & 9,867 & 369,0 & 6,90 & 36 & \multirow{3}{*}{$\begin{array}{c}\text { Menurun } \\
18 \% 13 \\
\text { Segmen }\end{array}$} & 0,25 & 10,711 & 500,8 & 7,33 \\
\hline 16 & & 0,5 & 9,660 & 324,2 & 6,75 & 37 & & 0,5 & 10,919 & 531,0 & 7,33 \\
\hline 17 & & 0,125 & 10,030 & 400,5 & 6,87 & 38 & & 0,125 & 10,542 & 467,3 & 7,07 \\
\hline 18 & \multirow{3}{*}{$\begin{array}{l}\text { Meningkat } \\
18 \% \\
5 \text { Segmen } \\
\end{array}$} & 0,25 & 9,971 & 389,2 & 6,89 & 39 & \multirow{3}{*}{$\begin{array}{c}\text { Menurun } \\
25 \% \\
13 \text { Segmen }\end{array}$} & 0,25 & 10,924 & 528,3 & 7,39 \\
\hline 19 & & 0,5 & 9,816 & 362,2 & 6,84 & 40 & & 0,5 & 11,244 & 561,7 & 7,62 \\
\hline 20 & & 0,125 & 10,093 & 412,8 & 6,92 & 41 & & 0,125 & 10,670 & 496,0 & 7,15 \\
\hline 21 & \multicolumn{2}{|c|}{ Homogen } & \multicolumn{3}{|c|}{$\begin{array}{c}\text { Frekuensi Tengah } \\
10,237 \mathrm{GHz}\end{array}$} & & \multicolumn{2}{|c|}{$\begin{array}{c}\text { BW di } \\
\text { VSWR }<1,5 \text { sebesar } \\
433,55 \mathrm{MHz}\end{array}$} & \multicolumn{3}{|c|}{ Gain 7,04635 dBi } \\
\hline
\end{tabular}

(bertambah) sebesar $1,0075 \mathrm{GHz}(9,842 \%)$ daripada frekuensi tengah dengan substrat homogen. Sedangkan, untuk mendapatkan nilai gain yang optimal digunakan substrat homogen dengan nilai permitivitas relatif diturunkan sebesar $25 \%$ pada frekuensi 11,24 GHz. Peningkatan nilai gain yang terjadi sebesar $1.004 \mathrm{dBi}(14,73 \%)$ dan nilai bandwidth yang terjadi sebesar 105,95 $\mathrm{MHz}(24,44 \%)$ daripada antena dengan substrat homogen.

Tabel 4. Menunjukkan hasil simulasi secara keseluruhan berdasarkan 2 simulator. FS adalah Frekuensi Sama dengan substrat tidak homogen terbaik. DS adalah Dimensi Sama dengan Homogen.

\section{KESIMPULAN}

Pada penelitian ini telah dilakukan simulasi pada antena dengan substrat tidak homogen pada frekuensi $X$ Band. Simulasi pada penelitian kali ini dilakukan dengan 3 skenario antena dengan substrat tidak homogen dan dapat disimpulkan Antena dengan substrat tidak homogen dapat mempengaruhi hasil dari performansi antena, yaitu pergeseran frekuensi tengah, nilai Bandwidth dan Gain. Konfigurasi substrat tidak homogen yang baik adalah ketika substrat memiliki banyak jumlah segmen dan ukuran dari setiap segmen diperbesar. Menaikkan nilai permitivitas dari nilai homogen dapat menggeser frekuensi tengah ke kiri (berkurang), tetapi akan menurunkan nilai bandwidth dan gain. Performansi antena yang paling baik berupa peningkatan bandwidth sebesar 128,15 $\mathrm{MHz}$ $(29,558 \%)$, gain sebesar $0.8076 \mathrm{dBi}(11,855 \%)$, dan frekuensi tengah dari antena bergeser ke kanan (bertambah) sebesar $1,0075 \mathrm{GHz}(9,842$

\section{Daftar Pustaka}

[1] C. A. Balanis, Antenna theory: analysis and design. John wiley \& sons, 2016.

[2] T. F. A. Nayna, A. Baki, and F. Ahmed, "Comparative study of rectangular and circular microstrip patch antennas in x band," in 2014 International Conference on Electrical Engineering and Information \& Communication Technology. IEEE, 2014, pp. 1-5.

[3] S. S. Bukhari and W. Whittow, "Heterogeneous substrate microstrip antenna with enhanced bandwidth," in 2013 Loughborough Antennas \& Propagation Conference (LAPC). IEEE, 2013, pp. 213-216. 
[4] W. G. Whittow, S. S. Bukhari, L. A. Jones, and I. L. Morrow, "Applications and future prospects for microstrip antennas using heterogeneous and complex 3-d geometry substrates," Progress In Electromagnetics Research, vol. 144, pp. 271-280, 2014.

[5] A. Kunwar, A. K. Gautam, and K. Rambabu, "Design of a compact $\mathrm{u}$-shaped slot triple band antenna for wlan/wimax applications," AEU-International Journal of Electronics and Communications, vol. 71, pp. 82-88, 2017.

[6] A. Lab Antena, Design of Array Antenna For Wireless Communication with CST. Antena Laboratory, 2017. 